\title{
Analisis Intention Mahasiswa Memilih Program Studi Akuntansi Menggunakan Theory of Plan Behavioral
}

\author{
Christopher Ryan Julian, Nathania, Golrida Karyawati P*, Siti Farhana \\ Program Studi Keuangan, Sekolah Bisnis dan Ekonomi Universitas Prasetiya Mulya \\ BSD City Kavling Edutown I.1 , Jl. BSD Raya Utama, BSD City, Tangerang 15339
}

Keywords:

Atitude, behavioral control, intention, Theory of Planned Behaviour (TPB), subjective norm

\section{Kata Kunci:}

Sikap, kontrol perilaku, intensi, Theory of plan behaviour (TPB), norma subjektif

\section{* Corresponding author:} golrida.karyawati@pmbs.ac.id

\begin{abstract}
This study aims to analyze student intentions in choosing an accounting major using Theory of Plan Behavior (TPB). TPB is used to determine whether the decision to take education in an accounting study program is a momentary decision or is the result of the behavior of the plan. This study is important given the issues regarding the industrial revolution 4.0. currently it is feared that it threatens the existence of accounting study programs in Indonesia. This study conducted a survey of 10 college majoring in accounting students in Greater Jakarta in Indonesia. Regression models are used to analyze the influence of attitudes, subjective norms and behavioral control in determining intentions to choose an accounting major. The results showed that the decision to choose an accounting major was based on intentions generated from the plan behaviour. The analysis also found that students with a science education background also chose accounting majors. The results of this study are expected to provide confidence to institutions that hold accounting study programs in carrying out their programs and adapt to changes caused by the industrial revolution 4.0.
\end{abstract}

\section{Sari Pati}

Penelitian ini bertujuan menganalisis niat (intention) mahasiswa dalam memilih jurusan akuntansi menggunakan Theory of Plan Behaviour (TPB). TPB digunakan untuk mengetahui apakah keputusan menempuh pendidikan pada program studi akuntansi dilakukan secara kebetulan atau dengan plan behaviour. Studi ini penting mengingat isu-isu mengenai teknologi dewasa ini dikhawatirkan mengancam keberlangsungan program studi akuntansi di Indonesia. Penelitian ini melakukan survei atas mahasiswa jurusan akuntansi 10 perguruan tinggi di Jabodetabek Indonesia.

Model regresi diterapkan untuk menganalisis pengaruh attitude, norma subjektif dan kontrol perilaku dalam menentukan intention memilih jurusan akuntansi. Hasil penelitian menunjukan bahwa keputusan memilih jurusan akuntansi adalah didasarkan intention yang merupakan hasil plan behaviour. Hasil analisis juga menemukan bahwa mahasiswa yang berlatar belakang pendidikan IPA juga memilih jurusan akuntansi. Hasil penelitian ini diharapkan memberi keyakinan kepada institusi yang menyelenggarakn program studi akuntansi dalam menjalankan programnya dan beradaptasi dengan perubahan yang disebabkan revolusi industri 4.0 . 


\section{Pendahuluan}

Isu bahwa revolusi industri 4.0 menggantikan sebagian peran akuntan dianggap merupakan fakta yang kurang menguntungkan bagi perguruan tinggi yang menyelenggarakan program studi akuntansi. Akhir-akhir ini banyak perguruan tinggi penyelenggara program studi akuntansi mulai mengkhawatirkan berkurangnya penerimaan mahasiswa jurusan akuntansi. Menurut Satya (2018), revolusi industri 4.0 hingga tahun 2030 menyebabkan 800 juta lapangan kerja di seluruh dunia diambil alih oleh mesin. Harususilo (2018) memperkirakan 10 pekerjaan yang diganti termasuk pekerjaan akunting dan payroll dengan robot akibat perubahan teknologi. Data Kementerian Riset Teknologi dan Perguruan Tinggi (2019) mengindikasikan mulai terjadi perlambatan peningkatan jumlah penerimaan mahasiswa akuntansi di Indonesia. Jumlah peningkatan penerimaan mahasiswa di tahun 2015 ke tahun 2016 adalah 4,72\%, sedangkan peningkatan di tahun 2016 ke 2017 adalah 0,92\%. Oleh sebab itu isu revolusi industri 4.0 perlu ditindaklanjuti oleh pendidikan tinggi.

Studi ini ingin menganalisis niat (intention) calon mahasiswa menempuh pendidikan pada program studi akuntansi dalam revolusi industri 4.0. Theory of Planned Behavior (TPB) diimplementasikan untuk menganalisis faktor-faktor yang mempengaruhi intention calon mahasiswa menempuh pendidikan program studi akuntansi. Dalam menganalisis faktorfaktor yang mempengaruhi intention, TPB fokus pada perilaku atau tindakan yang terencana yang lebih bersifat jangka panjang, bukan merupakan intention yang terjadi secara kebetulan, sehingga diharapkan dapat menjawab kekhawatiran institusi penyelenggaran program studi akuntansi mengenai keberlangsungan program studi akuntansi.

Isu mengenai prospek jurusan akuntansi telah menarik minat para peneliti termasuk dari berbagai negara, seperti Kuwait, Cina, Malaysia dan, Kamboja. Berbagai faktor diduga mempengaruhi intention mengambil jurusan akuntansi dianalisis, seperti nilai intrinsik, pasar kerja, prospek karir, teman, keluarga, guru, beban kerja, kemampuan matematis dan teknologi (Ali \& Tinggi, 2012; Law \& Yuen, 2011; Porter \& Woolley, 2014; Tang \& Seng, 2014; Yu, 2011; Wang \& Li, 2016; Noviari, 2009). Namun penelitian-penelitian tersebut cenderung dilakukan dalam konteks yang lebih sempit. Law dan Yuen (2011), Porter dan Woolley (2014), Wally dan Dima (2013), Ali dan Tinggi (2012), serta Rababah (2016) melakukan penelitian hanya pada satu kampus saja.

Di Indonesia, penelitian mengenai intention terhadap jurusan akuntansi juga cenderung dilakukan dalam satu kampus saja, seperti yang dilakukan oleh Suharti dan Sirine (2011), Cendrawi (2015), Wijayanti dan Putri (2016), Andika dan Madjid (2012), Islami (2015), Ali dan Tinggi (2012), Kamal dan Rahmadiane (2016), Sugahara, Suzuki dan Boland (2010) 
serta Puruhita dan Zaky (2014). Penelitian ini menganalisis bekerjanya TPB pada intention untuk menempuh pendidikan akuntansi pada sampel yang lebih luas yakni perguruan tinggi yang menyelenggarakan program studi akuntansi di Jabodetabek. Dengan sampel yang lebih luas, diharapkan hasil penelitian memiliki tingkat generalisasi yang lebih tinggi.

\section{Literatur Review dan Pengembangan Hipotesis}

\section{Intention dalam Theory of Planned Behaviour (TPB)}

TPB merupakan teori yang fokus pada behavioral intentions dalam mengambil keputusan yang didasari oleh keyakinan individu (Ajzen, 2005). Intention adalah hasil dari pikiran sadar yang mengarahkan tingkah laku seseorang (Parker, 2004). TPB menghubungkan intention dan perilaku (Ajzen, 2005). Namun intention dalam TPB adalah merupakan hasil perilaku terencana (Ajzen, 2005) dan bukan merupakan kebetulan. Intention yang lahir dari perilaku yang terencana memiliki probabilitas yang tinggi menjadi perilaku dan bersifat jangka panjang.

Intention dalam TPB dibentuk oleh 3 faktor yakni sikap (attitude), norma subjektif, dan kontrol perilaku (behavioral control). Attitude merupakan evaluasi kepercayaan atau perasaan positif atau negatif mengenai suatu perilaku (Hartono, 2008). Attitude lahir dari evaluasi subjektif atas konsekuensi suatu perilaku atas individu (Ajzen, 2005). Evaluasi subjektif tersebut dipengaruhi oleh pengalaman, pengetahuan tentang suatu hal, atau keyakinan mengenai konsekuensi dari suatu perilaku.

Ajzen (2005) mengukur attitude dengan dua komponen yakni belief strength dan outcome evaluation. Beliefs strength adalah besaran keyakinan individu terhadap suatu hal yang terbentuk dari latar belakang spiritual, etika, integritas dan kepercayaan dalam kehidupan sehari-hari (O’Bannon, 2015). Outcome evaluation merupakan keyakinan atas konsekuensi yang didapatkan dari suatu perilaku yang akan lakukan (Ajzen, 2005). Perbedaan beliefs strength dengan outcome evaluation adalah, beliefs strength merupakan keyakinan tanpa mempertimbangkan konsekuensi dari suatu perilaku, sementara outcome evaluation merupakan keyakinan terhadap konsekuensi dari suatu perilaku

Norma subjektif menurut Sugahar dan Bolland (2006) adalah tekanan sosial dari pihakpihak yang memiliki arti signifikan atau penting atas individu pengambil keputusan sehubungan dengan keputusan yang diambil. Pihak-pihak yang memiliki arti signifikan tersebut dapat berupa keluarga, penasihat, partner dan lainnya yang memiliki hubungan emosional dengan pembuat keputusan. 
Intention yang terbentuk dari norma subjektif selain terjadi karena kecenderungan individu pengambil keputusan untuk lebih mempercayai para pihak yang memiliki hubungan emosional dengannya, juga karena adanya norma atau budaya yang mengharuskan pembuat keputusan untuk menerima saran dari keluarga atau pihak-pihak lainnya yang memiliki peran signifikan. Intention yang terbentuk dari Norma subjektif ini diukur dengan normative belief dan motivation to comply (Ajzen, 2005). Intention yang terbentuk dari normative belief berasal dari keyakinan terhadap perilaku yang disarankan oleh para pihak yang memiliki ikatan emosional. Pandangan pihak-pihak yang memiliki ikatan emosional cenderung dianggap benar dan dijadikan acuan untuk melakukan atau tidak melakukan perilaku tertentu (Eagly dan Chaiken, 1993). Sedangkan Motivation to comply merupakan besaran motivasi untuk mengikuti pendapat atau pandangan para pihak yang memiliki ikatan emosional (Eagly dan Chaiken, 1993). Normative belief mengukur seberapa besar keyakinan individu terhadap pandangan orang lain namun tidak mengukur motivasi individu untuk mengikuti pandangan orang lain, sementara motivation to comply diperlukan untuk mengukur motivasi individu untuk mengikuti pandangan orang lain.

Kontrol perilaku merupakan persepsi atas kemudahan atau kesulitan dalam melaksanakan intention (Ajzen,1991). Kontrol perilaku ditentukan oleh ketersediaan sumberdaya seperti peralatan, kompetensi dan kesempatan yang mendukung atau menghambat perilaku. Individu yang memiliki kontrol perilaku yang tinggi akan berusaha hingga berhasil karena yakin akan sumberdaya dan kesempatan yang dimiliki, dan yakin bahwa kesulitan atau hambatan yang ada dapat diatasi.

Kontrol perilaku merefleksikan pengalaman masa lalu serta antisipasi terhadap halangan yang ada (Puruhita dan Zaky, 2014). Pengalaman tersebut menimbulkan kepercayaan diri terhadap kemampuan untuk memecahkan suatu masalah. Jika seseorang tidak percaya diri terhadap kemampuan dirinya, maka orang tersebut tidak akan memiliki intention untuk melakukan suatu tindakan (Ajzen, 2005). Ajzen (2005) mengukur kontrol perilaku dengan dua variabel yaitu Control Belief dan Power of Control.

Control Belief adalah kepercayaan atau keyakinan individu terhadap faktor yang dapat menghambat atau memfasilitasi individu dalam melakukan suatu perilaku tindakan (Ismail \& Zain, 2008). Power of Control adalah seberapa besar kepercayaan atau keyakinan individu untuk mendapatkan fasilitas atau mengatasi hambatan dalam melakukan suatu perilaku (Ajzen, 2005). Control belief fokus pada fasilitas atau hambatan, sedangkan power of control fokus pada keyakinan keberhasilan melakukan intention atau mengatasi hambatan demi keberhasilan intention (Bandura, 1977). 
TPB telah digunakan dalam menganalisis intention dalam berbagai bidang. Joeliatin et al. (2016) misalnya, menggunakan TPB untuk menganalisis intention wanita usia produktif menggunakan alat kontrasepsi jangka panjang. Hapsari dan Seta (2019) menggunakan TPB untuk menganalisis potensi kecurangan dan wishtleblowing. Agriyanto (2018) menggunakan TPB untuk menganalisis perilaku menggunakan informasi akuntansi berbasis akrual pada institusi pemerintahan. Suharti dan Sirine (2011) menganalisis faktor-faktor yang mempengaruhi kewirausahaan.

\section{Intention Memilih Jurusan Akuntansi}

Attitude dan Intention

Berbagai hasil penelitian membuktikan hubungan antara attitude dengan intention (Suharti dan Sirine, 2011; Islami, 2015; Harding et. al., 2007; Alleyne dan Phillips, 2011; Andika dan Madjid, 2012). Suharti dan Sirine (2011) menemukan attitude berpengaruh positif terhadap intention berwirausaha didorong keinginan untuk memilki otoritas, nilai ekonomi tinggi, keyakinan diri, serta kreatifitas individu. Harding et al. (2007) membuktikan bahwa attitude berpengaruh signifikan terhadap intention melakukan kecurangan akademik. Hasil yang serupa juga ditemukan dalam penelitian Alleyne dan Phillips (2011). Yu (2011) meneliti faktor-faktor yang mempengaruhi calon mahasiswa memilih jurusan Sport Management pada perguruan tinggi di Taiwan, dan menemukan bahwa attitude memiliki pengaruh yang paling kuat diantara faktor-faktor TPB lainnya.

Penelitian yang dilakukan oleh Law dan Yuen (2011), Law (2010), Wally dan Dima (2013), Law (2010), Ningsih dan Zaky (2014), Puruhita dan Zaky (2014), dan Cendrawi (2015) menemukan bahwa attitude berpengaruh signifikan terhadap pemilihan jurusan akuntansi. Puruhita dan Zaky (2014) memandang bahwa Jurusan akuntansi dianggap memiliki pendapatan dan pilihan karir yang baik. Menurut penelitian Cendrawi (2015) attitude atas pemilihan jurusan akuntansi didorong oleh tren pekerjaan yang tersedia serta pengetahuan tentang jurusan akuntansi yang cukup tinggi.

Penelitian-penelitian terdahulu membuktikan bahwa attitude dalam memilih jurusan akuntansi disebabkan oleh nilai intrinsik, prospek karir, dan pasar kerja (Law \& Yuen, 2011; Porter \& Woolley, 2014; Tang \& Seng, 2014; Yu, 2011). Menurut Andika dan Madjid (2012) attitude merupakan faktor internal yang paling dominan dibandingkan dengan norma subjektif dan kontrol perilaku.

Ali dan Tinggi (2012), Sumaryono dan Sukanti (2016), serta Tang dan Seng (2016) mengatakan bahwa ada tiga aspek yang dapat mempengaruhi attitude, yakni: nilai intrinsik 
atau kepuasan individu ketika melakukan suatu perbuatan, prospek karir, dan pasar kerja. Hasil penelitian Alanezi et al. (2016) menyatakan bahwa prospek karir dan mata kuliah akuntansi yang menarik yang mempengaruhi intention menempuh pendidikan akuntansi.

Hipotesis pertama dari penelitian ini:

Hipotesis 1: Attitude berpengaruh signifikan terhadap keputusan mahasiswa memilih jurusan akuntansi.

\section{Norma Subjektif dan Intention}

TPB mengatakan bahwa norma subjektif mempengaruhi intention (Ajzen, 2005). Tang dan Seng (2016) menghindikasikan bahwa pendapat keluarga dan kerabat dekat berpengaruh positif terhadap keputusan memilih jurusan akuntansi. Puruhita dan Zaky (2014) menemukan norma subjektif berpengaruh terhadap pengambilan jurusan akuntansi. Akan tetapi hasil penelitian Ali dan Tinggi (2012) menyatakan bahwa mahasiswa tetap memilih jurusan akuntansi meskipun orang tua dan kerabat mahasiswa tidak menyarankan mengambil jurusan akuntansi. Penelitian Ningsih dan Zaky (2014), Islami (2015) dan Cendrawi (2015) juga belum menemukan pengaruh norma subjektif terhadap intention. Menurut Cendrawi (2015) attitude lebih mempengaruhi intention memilih jurusan akuntansi dibanding norma subjektif. Hasil penelitian Yu (2011) terhadap mahasiswa di Taiwan juga menemukan bahwa intention kurang dipengaruhi oleh norma subjektif jika dibandingkan dengan faktor-faktor TPB lainnya.

Law dan Yuen (2011) menemukan kecenderungan mahasiswa di Hong Kong atau Asia mengikuti saran dari orang tua atau kerabat dekat mereka. Hal ini didorong oleh adanya budaya konfusius yang sudah ditanamkan sejak dini. Penelitian mengenai intention melakukan kecurangan akademik menemukan bahwa norma subjektif berpengaruh terhadap intention melakukan kecurangan akademik (Harding et al., 2007; Alleyne dan Phillips, 2011; Wijayanti dan Putri, 2016; Andika dan Madjid, 2012). Sulistiani dan Prastiwi (2012) menyimpulkan bahwa norma subjektif berpengaruh signifikan terhadap intention berkarir sebagai akuntan publik.

Menurut Ajzen (2005) pengaruh norma subjektif terhadap intention dibentuk dari pentingnya pendapat para pihak yang signifikan bagi pembuat keputusan, dan kuatnya motivasi untuk memenuhi harapan para pihak yang signifikan bagi individu pembuat keputusan. Norma subjektif biasanya berasal dari keluarga, teman, guru, panutan (role model), media internet, dan lainnya (Law \& Yuen, 2011; Tang \& Seng, 2014; Wang \& Li, 2016; Porter \& woolley, 2014; Yu, 2011). Hipotesis kedua adalah: 
Hipotesis 2: Norma subjektif berpengaruh signifikan terhadap keputusan mahasiswa memilih jurusan akuntansi.

\section{Kontrol perilaku dan Intention}

Alanezi, Alfraih, Haddad, Ali dan Tinggi (2012), Sumaryono dan Sukanti (2016), serta Tang dan Seng (2016) menyebutkan beberapa aspek kontrol perilaku dalam menentukan intention memilih jurusan akuntansi antara lain: pengetahuan akuntansi, kemampuan matematika, beban kerja, pengetahuan akuntansi, dan lainnya. Penelitian yang dilakukan oleh Porter \& Woolley (2014), Sugahara, Suzuki \& Boland (2010), Ningsih dan Zaky (2014) belum menemukan pengaruh kontrol perilaku terhadap pemilihan jurusan akuntansi. Namun isu revolusi 4.0 mengenai lapangan pekerjaan akuntan yang banyak diganti mesin menjadikan isu tersebut menjadi salah satu aspek kontrol perilaku yang patut diperhitungkan. Berkurangnya lapangan kerja pada level tertentu telah menimbulkan kehawatiran bagi peminat jurusan akuntansi

Sugahara dan Bolland (2006) menemukan bahwa kontrol perilaku berpengaruh signifikan terhadap pemilihan karir CPA. Penelitian dari Cendrawi (2015) menyatakan kontrol perilaku memiliki pengaruh yang signifikan terhadap pemilihan jurusan akuntansi. Cendrawi (2015) menjelaskan bahwa hasil ini didorong pengetahuan responden yang tinggi terhadap ilmu akuntansi sebelum memasuki universitas. Hasil pengujian intention mahasiswa berlatar belakang IPA yang dilakukan Puruhita dan Zaky (2014) juga menemukan bahwa kontrol perilaku berpengaruh signifikan dalam pemilihan jurusan akuntansi mahasiswa yang berlatar belakang IPA. Hipotesis ketiga dinyatakan sebagai berikut:

Hipotesis 3: Kontrol perilaku berpengaruh signifikan terhadap keputusan mahasiswa memilih jurusan akuntansi.

\section{Kerangka Pemikiran}

Berdasarkan telaah literatur dan pengembangan hipotesis yang sudah dijabarkan di atas, maka kerangka pemilim un menguji hipotesis dapat digambarkan sebagai berikut:

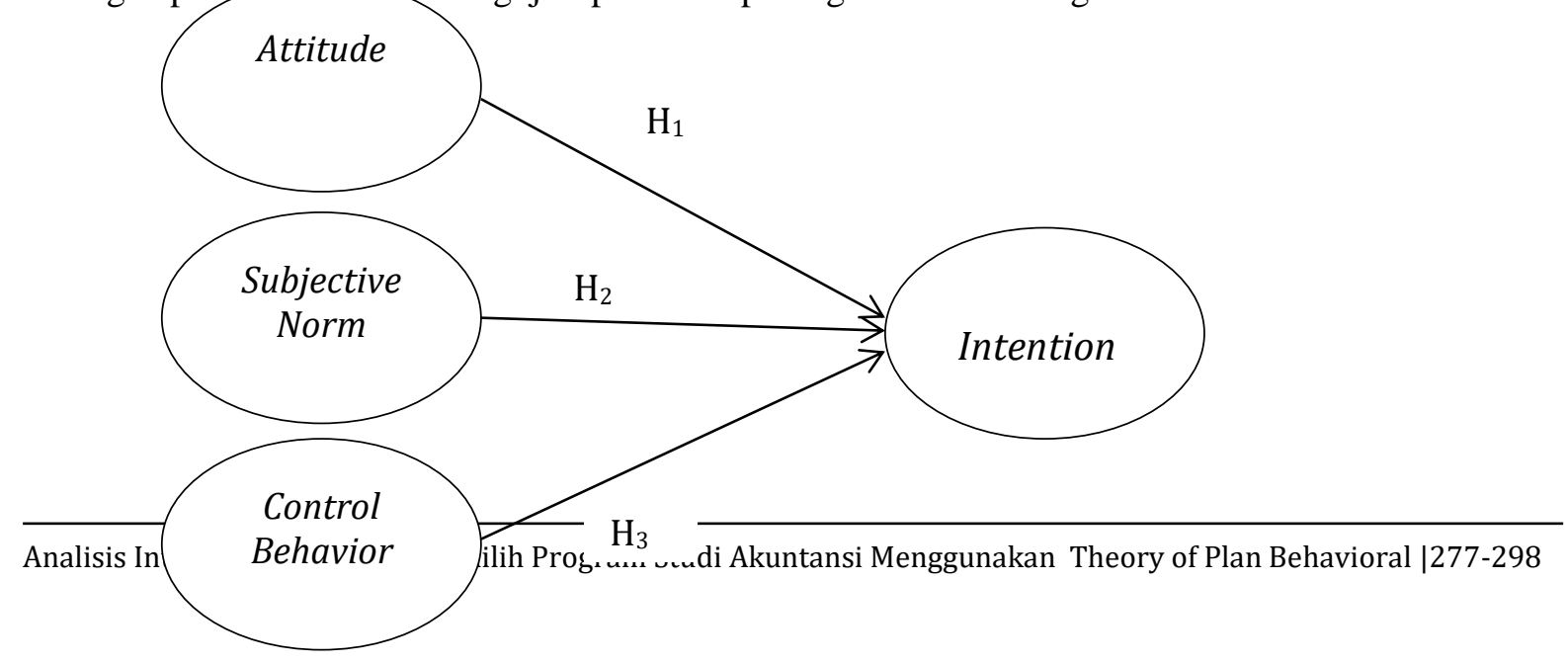




\section{Gambar 1. Kerangka Pemikiran}

Sumber: Replikasi model Theory of Planned Behavioral (Azjen, 2005)

\section{Metode Penelitian}

\section{Pengumpulan Data}

Penelitian ini melakukan survei mengenai intention mahasiswa dalam memilih jurusan akuntansi pada perguruan tinggi Indonesia menggunakan TPB. Penelitian ini menganalisis 3 variabel yang mempengaruhi intention menurut TPB yakni attitude yang jabarkan dalam 2 dimensi yakni belief strength dan outcome evaluation, norma subjektif yang jabarkan dalam dimensi normative belief dan dimensi outcome evaluation, dan kontrol perilaku yang dipandang dari dimensi control belief dan dimensi power of control.

Survei dilakukan menggunakan daftar kuesioner yang diolah berdasarkan penelitian terdahulu, seperti Ali dan Tinggi (2012), Law dan Yuen (2011), Noviari (2009), Porter dan Woolley (2014), Tang dan Seng (2016), Wang dan Li (2016), Yu (2011). Setiap variabel diturunkan dalam pertanyaan-pertanyaan yang mencakup kedua dimensi variabel. Penelitian ini melakukan pemutahiran atas daftar pertanyaan penelitian terdahulu melalui focus group discussion (FGD). FGD menghasilkan penambahan 3 aspek dimensi variabel norma subjektif dan 2 aspek pada variabel kontrol perilaku. Daftar pertanyaan yang telah melalui proses FGD diuji validitas dan uji reliabilitasnya dengan menyebarkan kuesioner pada 30 calon responden.

Uji validitas dengan cara membandingkan nilai $r$ hitung dengan $r$ tabel pada degree of freedom $(\mathrm{df})=\mathrm{n}-2$ (jumlah sampel dikurang 2). Jika $\mathrm{r}$ hitung lebih besar dari $\mathrm{r}$ tabel dan nilai positif maka dapat dinyatakan bahwa pertanyaan dalam kuesioner sudah valid. Uji reliabilitas yang digunakan adalah koefisien Cronbach's Alpha. Hasil dari uji validitas dan uji reliabilitas menunjukan bahwa seluruh pertanyaan sudah valid dan reliable. Daftar pertanyaan disajikan pada tabel 4.

\section{Variabel Penelitian}

Penelitian ini ingin menganalisis faktor-faktor yang mempengaruhi intention menurut TPB. Variabel penelitian independen adalah attitude, norma subjektif dan kontrol perilaku, sedangkan variabel dependen adalah intention. Variabel penelitian dikembangkan menjadi daftar pertanyaan sebagaimana tersaji pada Lampiran 1. Ketiga variabel independen yang dianalisis terdiri dari 14 aspek penilaian. Variabel attitude yang meliputi dimensi belief strength dan outcome evaluation dianalisis dalam aspek nilai intrinsik, pasar kerja dan prospek karir. Dari ketiga aspek tersebut disusun 
12 pertanyaan dimana 6 pertanyaan mengenai belief strength dan 6 pertanyaan mengenai outcome evaluation.

Variabel norma subjektif dianalisis dalam 6 aspek yakni: keluarga, teman, guru, panutan (role model), pihak kampus, dan media internet dimana setiap aspek memenuhi dimensi normative belief dan motivatiation to complete. Adapun variabel kontrol perilaku dianalisis dalam 5 aspek yakni: beban kerja, pengetahuan matematika, pemahaman ekonomi, pengetahuan akuntansi, dan penguasaan teknologi. Setiap aspek meliputi kedua dimensi kontrol perilaku yakni: control belief dan dimensi power of control.

Setiap pertanyaan dinilai dengan skala likert dengan kriteria penilaian sebagai berikut: Apabila jawaban responden berada diatas nilai median menunjukan plan behaviour yang semakin kuat. Nilai median untuk variabel intention adalah 3. Namun, karena setiap variabel independen memiliki 2 dimensi maka akumulasi skala terendah adalah 1 (1x1) dan skala tertinggi adalah 25 (5 x5). Dengan demikian median variabel independen adalah 13. Jawaban atas suatu aspek dalam variabel independen yang berada diatas nilai 13 menunjukan plan behaviour yang semakin kuat.

\section{Sampel}

Responden penelitian ini adalah mahasiswa tingkat satu jurusan akuntansi pada perguruan tinggi daerah Jabodetabek. Untuk mengontrol agar intention mahasiswa dalam memilih jurusan akuntansi adalah merupakan hasil perencanaan yang matang sesuai dengan TPB, penelitian ini menetapkan kriteria perguruan tinggi yang menjadi sampel penelitian adalah perguruan tinggi yang lebih sulit diraih. Kriteria pertama adalah, biaya perkuliahan diatas rata-rata Indonesia. Kriteria kedua adalah akreditasi program studi minimal B. Terdapat 10 universitas yang masuk ke dalam sampel tersaji pada tabel 1. Selain 10 universitas tersebut terdapat 3 universitas yang memenuhi kriteria seperti Swiss German University, Podomoro University, dan Sampoerna University. Namun jumlah mahasiswa terlalu sedikit dan diragukan keaktifannya, sehingga 3 universitas tersebut dikeluarkan dari sampel. Kolom akhir pada tabel 1 menunjukan jumlah minimal responden dari masing-masing perguruan tinggi. Jumlah tersebut telah memenuhi persyaratan minimal yang disajikan rumus slovin sebagai berikut:

$$
n=\frac{N}{N\left(d^{2}\right)+1}
$$

dimana:

$\mathrm{n}=$ jumlah sampel

$\mathrm{N}=$ total populasi

$\mathrm{d}=$ level of presisi $10 \%$

Berdasarkan perhitungan rumus Slovin jumlah minimal sampel adalah 96 seperti tersaji pada tabel1. 
Tabel 1 Deskripsi Populasi

\begin{tabular}{|l|c|c|c|}
\hline \multicolumn{1}{|c|}{ Universitas } & $\begin{array}{c}\text { Jumlah } \\
\text { Mahasiswa }\end{array}$ & Responden & $\begin{array}{c}\text { Minimal } \\
\text { Responden }\end{array}$ \\
\hline Universitas Prasetiya Mulya (PM) & 95 & 85 & 3 \\
\hline President University (PU) & 70 & 22 & 2 \\
\hline STIE Trisakti (TSM) & 462 & 16 & 16 \\
\hline Universitas Indonesia (UI) & 313 & 25 & 11 \\
\hline Universitas Binus (BNS) & 222 & 36 & 8 \\
\hline Universitas Atma Jaya (ATM) & 302 & 45 & 11 \\
\hline Kwik Kian Gie School of Business (KKG) & 220 & 8 & 8 \\
\hline Universitas Multimedia Nusantara (UMN) & 197 & 20 & 7 \\
\hline Universitas Tarumanagara (UTR) & 582 & 76 & 21 \\
\hline Universitas Pelita Harapan (UPH) & 243 & 54 & 9 \\
\hline TOTAL & $\mathbf{2 . 7 0 6}$ & $\mathbf{3 8 7}$ & $\mathbf{9 6}$ \\
\hline
\end{tabular}

Pengumpulan data dilakukan dengan membagikan kuesioner secara langsung dan dengan bantuan Himpunan Mahasiswa Akuntansi (HIMA) dengan mengisi Google Form. Data yang telah terkumpul di cek kelengkapannya. Data yang tidak lengkap akan dikeluarkan dari sampel. Data yang memiliki jawaban ekstrim seperti menjawab semua pertanyaan dengan jawaban yang sama juga dikeluarkan dari analisis.

\section{Analisis Regresi}

Penelitian ini menggunakan Model regresi adalah sebagai berikut:

$$
A C C_{i}=\beta_{0}+\beta_{1} A T B_{i}+\beta_{2} S N_{i}+\beta_{3} P B C_{i}+\varepsilon_{i}
$$

Dimana:

$A C C_{i}=$ Intention memilih program studi akuntansi

$S K_{i} \quad=$ Attitudes

$N S_{i} \quad=$ Norma subjektif

$K P_{i} \quad=$ Kontrol perilaku

$\varepsilon_{i} \quad=$ Error

Pengujian hipotesis dilakukan berdasarkan model regresi yang telah dapat digunakan untuk memprediksi pengaruh ketiga variabel independen secara bersama-sama terhadap variabel dependen. 


\begin{tabular}{lccc} 
& Jumlah Responden & \multicolumn{2}{c}{ Jurusan } \\
\cline { 3 - 4 } Universitas & & IPA & IPS dan Akuntansi \\
\hline Universitas Prasetiya Mulya & 55 & 33 & 52 \\
President University & 22 & 10 & 12 \\
STIE Trisakti (TSM) & 16 & 7 & 9 \\
Universitas Indonesia & 25 & 9 & 16 \\
Universitas Bina Nusantara & 36 & 22 & 14 \\
Universitas Atmajaya & 45 & 21 & 24 \\
IBII & 8 & 3 & 5 \\
Universitas Multimedia Nusantara & 20 & 10 & 10 \\
Universitas Tarumanagara & 76 & 33 & 43 \\
Universitas Pelita Harapan & 54 & 24 & 30 \\
\hline Total & $\mathbf{3 8 7}$ & $\mathbf{1 7 2}$ & $\mathbf{2 1 5}$ \\
\hline Persentase & - & $\mathbf{4 4 , 4 4 \%}$ & $\mathbf{5 5 , 5 6 \%}$ \\
\hline
\end{tabular}

\section{Hasil Pengujian}

\section{Deskripsi Statistik}

Deskripsi responden yang menjadi sampel penelitian disajikan pada tabel 2. Meskipun lebih banyak responden yang menjadi mahasiswa program studi akuntansi memiliki latar belakang pendidikan ilmu sosial yakni 55,56\%, namun jumlah mahasiswa yang berlatar belakang IPA merupakan jumlah yang besar yakni 44,44\%. Tabel 3 menyajikan statistik deskriptif dari variabel dependen yakni intention, dan ketiga variabel independen yakni: attitude, norma subjektif dan behavioral control. Mean value intention sebesar 3,55 adalah berada diatas nilai median yang menunjukan intention mahasiswa memilih program studi akuntansi cukup kuat.

Dari ketiga variabel independen, variabel attitude memiliki mean value diatas 13 atas seluruh aspek analisis. Hal ini mencerminkan kuatnya plan behaviour terhadap intention memilih jurusan akuntansi. Aspek pasar kerja dengan mean value 16,32 merupakan aspek attitude yang paling kuat plan behaviour nya terhadap pemilihan program studi akuntansi. Prospek karir juga memiliki mean value yang relatif jauh diatas nilai median. Terlepas dari berbagai berita negatif mengenai menghilangnya berbagai pekerjaan yang berhubungan dengan akuntansi (kompas.com, 2018; Satya, 
2018) kenyataannya lowongan pekerjaan akuntansi masih terbuka lebar. Menurut antaranews.com (2019) Indonesia masih membutuhkan 12,000 akuntan sedangkan saat ini akuntan aktif di Indonesia hanya 4,000 .

Tabel 3 Deskripsi Statistik

\begin{tabular}{|c|c|c|c|c|}
\hline Aspek & $\mathbf{N}$ & Pertanyaan & Mean & Median \\
\hline Intention & 387 & 1 & 3,55 & 3 \\
\hline \multicolumn{5}{|l|}{ Attitudes } \\
\hline A_16 $\rightarrow$ Nilai intrinsik & 387 & 6 & 13,33 & 13 \\
\hline A_78 $\rightarrow$ Pasar kerja & 387 & 2 & 16,32 & 13 \\
\hline A_912 $\rightarrow$ Prospek karir & 387 & 4 & 15,35 & 13 \\
\hline Total Attitudes & 387 & 12 & 15 & 13 \\
\hline \multicolumn{5}{|l|}{ Norma subjektif } \\
\hline B_12 $\rightarrow$ Keluarga & 387 & 2 & 14,68 & 13 \\
\hline B_34 $\rightarrow$ Teman/kolega & 387 & 2 & 6,76 & 13 \\
\hline B_56 $\rightarrow$ Teachers & 387 & 2 & 7,08 & 13 \\
\hline B_78 $\rightarrow$ Panutan (role model) & 387 & 2 & 7,59 & 13 \\
\hline B_910 $\rightarrow$ Representasi universitas & 387 & 2 & 6,39 & 13 \\
\hline B_1112 $\rightarrow$ Internet & 387 & 2 & 7,85 & 13 \\
\hline Total Norma subjektif & 387 & 12 & 8,39 & 13 \\
\hline \multicolumn{5}{|l|}{ Behavioral control } \\
\hline C_12 $\rightarrow$ Beban kerja & 387 & 2 & 10,80 & 13 \\
\hline C_34 $\rightarrow$ Kemampuan matematika & 387 & 2 & 11,87 & 13 \\
\hline C_56 $\rightarrow$ Kemajuan teknologi & 387 & 2 & 10,75 & 13 \\
\hline C_78 $\rightarrow$ Pengetahuan akuntansi & 387 & 2 & 13,40 & 13 \\
\hline C_910 $\rightarrow$ Pemahaman ilmu ekonomi & 387 & 2 & 11,90 & 13 \\
\hline Total Behavioral control & 387 & 10 & 11,74 & 13 \\
\hline
\end{tabular}

Pada variabel norma subjektif walaupun hanya aspek keluarga yang memiliki mean value di atas nilai median namun mean value sebasar 14,68 tersebut relatif jauh diatas nilai median. Hal ini juga menunjukan bahwa variabel norma subjektif kuat dalam menentukan intention memilih program studi akuntansi. Adalah menjadi catatan bahwa aspek guru dan universitas kurang menjadi rujukan bagi mahasiswa dalam memilih jurusan akuntansi. Statistik deskriptif menunjukan kedua variabel berada jauh dibawah nilai median. Mean value pihak universitas bahkan yang terendah diantara dari seluruh aspek dalam variabel norma subjektif seperti tersaji pada tabel 3.

Seperti halnya variabel norma subjektif, Plan behaviour yang kuat dari variabel control behavior hanya berasal dari satu aspek yakni pengetahuan akuntansi dengan mean value 13,4. 
Temuan ini menarik mengingat pemilih jurusan akuntansi juga banyak yang berlatar belakang IPA yang relatif tidak memiliki pengetahuan akuntansi sebelumnya atau bahkan kurang mengenal bidang studi akuntansi dibanding mahasiswa berlatar belakang IPS dan akuntansi. Penelitian ini juga menganalisis Plan behaviour khusus mahasiswa akuntansi yang berlatar belakang IPA sebagaimana tersaji pada tabel 4 .

Tabel 4. Deskripsi Statistik Responden Berlatar Belakang IPA

\begin{tabular}{|c|c|c|c|c|}
\hline Aspek & $\mathbf{N}$ & Pertanyaan & Mean & Median \\
\hline Intention & 172 & 1 & 3,55 & 3 \\
\hline \multicolumn{5}{|l|}{ Attitudes } \\
\hline A_16 $\rightarrow$ Nilai intrinsik & 172 & 6 & 13,57 & 13 \\
\hline A_78 $\rightarrow$ Pasar kerja & 172 & 2 & 15,95 & 13 \\
\hline A_912 $\rightarrow$ Prospek karir & 172 & 4 & 16,70 & 13 \\
\hline Total Attitudes & 172 & 12 & 15,41 & 13 \\
\hline \multicolumn{5}{|l|}{ Norma subjektif } \\
\hline B_12 $\rightarrow$ Keluarga & 172 & 2 & 16,38 & 13 \\
\hline B_34 $\rightarrow$ Teman/kolega & 172 & 2 & 6.03 & 13 \\
\hline B_56 $\rightarrow$ Teachers & 172 & 2 & 5,65 & 13 \\
\hline B_78 $\rightarrow$ Panutan (role model) & 172 & 2 & 7,48 & 13 \\
\hline B_910 $\rightarrow$ Representasi universitas & 172 & 2 & 5,69 & 13 \\
\hline B_1112 $\rightarrow$ Internet & 172 & 2 & 7,16 & 13 \\
\hline Total Norma subjektif & 172 & 12 & 8,07 & 13 \\
\hline \multicolumn{5}{|l|}{ Behavioral control } \\
\hline C_12 $\rightarrow$ Beban kerja & 172 & 2 & 11,28 & 13 \\
\hline C_34 $\rightarrow$ Kemampuan matematika & 172 & 2 & 12,42 & 13 \\
\hline C_56 $\rightarrow$ Kemajuan teknologi & 172 & 2 & 12,16 & 13 \\
\hline C_78 $\rightarrow$ Pengetahuan akuntansi & 172 & 2 & 13 & 13 \\
\hline C_910 $\rightarrow$ Pemahaman ilmu ekonomi & 172 & 2 & 11,65 & 13 \\
\hline Total Behavioral control & 172 & 10 & 12,10 & 13 \\
\hline
\end{tabular}

Mean value aspek pengetahuan akuntansi responden berlatar belakang IPA 13 responden berlatar belakan IPA tidak berada diatas nilai median yang artinya plan behaviour dari aspek ini tidak cukup kuat dalam menentukan intention memilih program studi akuntansi. Namun mengingat bahwa mahasiswa berlatar IPA yang relatif kurang mengenal bidang akuntansi sebelumnya mean value ini menunjukan bahwa bagi mahasiswa yang berlatar belakang IPA ternyata pengetahuan akuntansi 
bukan hal yang menakutkan. Bahkan pengetahuan akuntansi juga merupakan aspek yang paling kuat plan behaviour-nya dibanding aspek lainnya dalam variabel kontrol perilaku. Terdapat kemungkinan bahwa walaupun mahasiswa tersebut memilih jurusan IPA di SMA namun telah merencanakan untuk menempuh pendidikan akuntansi di perguruan tinggi. Hal ini diperkuat dengan mean value pada aspek matematika mahasiswa yang berlatar belakang IPA yang berada dibawah nilai median. Hal ini memperkuat indikasi bahwa mahasiswa yang berlatar belakang IPA lebih mempersiapkan diri untuk menempuh jurusan sosial dibanding jurusan eksakta yang membutuhkan matematika lebih kompleks.

Dari tabel 3 dan tabel 4 dapat dilihat bahwa selain aspek pengetahuan akuntansi, aspek-aspek lainnya dari variabel attitude dan variabel norma subjektif adalah relatif tidak berbeda antara keseluruhan responden dengan responden berlatar belakang IPA, yakni: prospek karir dan aspek pasar kerja (variabel attitude), dan aspek keluarga (variabel norma subjektif). Ketiga aspek tersebut memiliki mean value yang sangat jauh diatas nilai median seperti tersaji pada tabel 4 . Temuan ini menjelaskan fakta besarnya jumlah responden berlatar belakang IPA yang memilih program studi akuntansi.

\section{Hasil Pengujian Regresi}

Hasil uji regresi disajikan pada tabel 5. Hasil pengujian regresi telah memenuhi uji asumsi klasik yakni uji normalitas, heteroskedastisitas, dan multikolinieritas. Nilai F sebesar 104,58 yang disajikan pada tabel 5 menunjukan bahwa model regresi adalah signifikan dan dapat digunakan dalam memprediksi hubungan variabel Attitude, Norma Subjektif dan kontrol perilaku secara bersama-sama terhadap intention memilih program studi akuntansi. Nilai $R$-squared pada tabel 5 menunjukan ketiga variabel independen secara bersama sama mampu menjelaskan variabel intention sebesar 45,03\%.

Tabel 5 Hasil Pengujian Regresi

\begin{tabular}{llccc}
\hline $\mathbf{N}$ & Independen Variabel & Coefficient & $\mathbf{t}$ & $\mathbf{P}-$ value \\
\hline 387 & Attitudes & 0,0178634 & 9,28 & $0,000 * * *$ \\
387 & Norma subjektif & 0,0187003 & 9,22 & $0,000 * * *$ \\
387 & Behavioral Control & 0,0068195 & 2,52 & $0,012 * *$ \\
387 & Cons. & 0,651057 & 3,66 & 0,000 \\
\hline *** Significant at the 1\% level; ** Significant at the 5\% level; * Significant at the 10\% level. \\
$\boldsymbol{F}(\mathbf{3 , 3 8 3 )}=\mathbf{1 0 4 , 5 8}$ \\
$\begin{aligned} \boldsymbol{P r o b}>\boldsymbol{F}=\mathbf{0 , 0 0 0} \\
\boldsymbol{R} \text {-Squared }=\mathbf{0 , 4 5 0 3}\end{aligned}$
\end{tabular}


Hasil pengujian ketiga variabel independen terhadap variabel dependen seluruh responden yang disajikan pada tabel 5 menunjukan bahwa ketiga variabel independen yakni attitude, norma subjektif dan kontrol perilaku berpengaruh positif terhadap intention. P-value dari ketiga variabel independen adalah signifikan yakni, attitude 0,000, norma subjektif 0,000, dan kontrol perilaku 0,012. Hasil ini sejalan dengan penelitian dari Harding et. al. (2007), Alleyne dan Phillips (2011), Andika dan Madjid (2012), serta Puruhita dan Zaky (2014).

Penelitian ini lebih jauh menguji kembali hubungan antara ketiga variabel independen terhadap intention atas responden yang berlatar belakang IPA. Hasil regresi atas mahasiswa berlatar belakang IPA disajikan pada tabel 6 .

Tabel 6 Hasil pengujian regresi responden berlatar belakang IPA

\begin{tabular}{clccc}
\hline $\mathbf{N}$ & Independent Variabel & Coefficient & t & P - value \\
\hline 172 & Attitudes & 0,0165273 & 5,88 & $0,000 * * *$ \\
172 & Norma subjektif & 0,0234797 & 7,03 & $0,000 * * *$ \\
172 & Behavioral Control & 0,0060385 & 1,47 & 0,145 \\
172 & Cons. & 0,561737 & 1,78 & 0,076 \\
\hline
\end{tabular}

*** Significant at the 1\% level; ** Significant at the 5\% level; * Significant at the $10 \%$ level. $F(3,1683)=40,62$

Prob $>F=0,000$

R-Squared $=0,4204$

Hasil uji t responden berlatar belakang IPA menunjukan hanya dua variabel independen yang berpengaruh terhadap intention yakni, attitude dan norma subjektif dengan $P$-value masing-masing 0,000. Adapun kontrol perilaku pada tabel 6 tidak berpengaruh signifikan terhadap intention. Signifikannya hubungan variabel norma subjektif dengan intention memilih program studi akuntansi pada mahasiswa berlatar belakang IPA disebabkan oleh aspek keluarga karena dari ke-6 aspek variabel norma subjektif hanya aspek famili yang memiliki mean value diatas nilai median. Namun hasil pengujian variabel kontrol perilaku mengindikasikan bahwa pengetahuan akuntansi yang memiliki mean value sebesanr 13 meskipun tertinggi diantara 5 aspek dalam variabel kontrol perilaku, tidak cukup kuat mempengaruhi intention mahasiswa berlatar belakang IPA memilih program studi akuntansi. Dengan demikian intention mahasiswa berrlatar belakang IPA memilih program studi akuntansi hanya didasarkan oleh keseluruhan aspek attitude dan aspek famili dari variabel norma subjektif. 


\section{Pembahasan}

Hasil penelitian menunjukan bahwa intention untuk menempuh jurusan akuntansi masih cukup kuat sampai saat ini. Ketiga variabel dalam TPB yakni attitude, norma subjektif dan kontrol perilaku terbukti signifikan mempengaruhi intention memilih jurusan akuntansi. Dari ketiga variabel yang mempengaruhi intention, attitude yang paling mendominasi termasuk pada mahasiswa berlatar belakang IPA. Hal ini sesuai dengan temuan Andika dan Madjid (2012). Aspek pasar kerja dan prospek karir bahkan sangat kuat membentuk attitude mahasiswa yang menempuh jurusan akuntansi (Alanezi et al, 2016). Media sosial yang sering menginformasikan kebutuhan akuntan membentuk persepsi positif calon mahasiswa terhadap jurusan akuntansi. Menurut Antaranews.com (2019) Indonesia masih membutuhkan 12,000 akuntan sedangkan saat ini akuntan aktif di Indonesia hanya 4,000 .

Budaya Asia atau budaya timur hingga saat ini masih dipegang oleh mahasiswa Indonesia, dalam mementukan pendidikan yang akan ditempuh, sebagaimana diindikasikan oleh Law dan Yuen (2016) dan Tan dan Laswad (2006). Hasil pengujian menunjukkan norma subjektif dari aspek keluarga signifikan mempengaruhi intention memilih program studi akuntansi seluruh responden. Istifarani (2016) mengatakan bahwa keluarga merupakan kesatuan yang fundamental dan utama yang berpengaruh signifikan terhadap pengambilan keputusan individu. Hasil pengujian ini mengindikasikan perlunya program studi akuntansi membangun hubungan yang baik dengan keluarga mahasiswa untuk meningkatkan intention calon mahasiswa memilih program studi akuntansi.

Hasil survei menemukan bahwa peminat jurusan akuntansi bukan hanya mahasiswa yang berlatar belakang IPS dan akuntansi yang telah mengenal jurusan akuntansi sebelumnya, namun juga mahasiswa yang berlatar belakang IPA. Alanezi et al. (2016) menemukan bahwa latar belakang pendidikan tidak berdampak signifikan dalam menentukan intention memilih jurusan akuntansi. Ketika dilakukan pengujian terpisah atas responden berlatar belakang IPA, perbedahaan hasil pengujian hanya terdapat pada variabel kontrol perilaku, dimana pada responden berlatar belakang IPA, variabel tersebut tidak signifikan mempengaruhi intention. Dengan demikian tingginya peminat 
program studi akuntansi dari responden yang berlatar belakang IPA utamanya disebabkan oleh prospek karir, pasar kerja dan saran keluarga.

Temuan yang menarik mengenai intention mahasiswa berlatar belakang IPA adalah bahwa walaupun relatif kurang memiliki pengetahuan akuntansi sebelumnya namun bagi mahasiswa berlatar belakang IPA pengetahuan akuntansi bukan merupakan hal yang sangat ditakutkan. Hasil analisis mengindikasikan bahwa mahasiswa yang berlatar belakang IPA bahkan telah merencanakan untuk memilih program studi akuntansi ketika masih berada di SMA sebagaimana temuan Wally dan Dima (2013) di Botswana. Hasil analisis ini merupakan informasi yang baik bagi penyelenggara program studi akuntansi untuk membangun optimisme ditengah-tengah isu yang cenderung negatif mengenai keberlanjutan program studi akuntansi.

Hasil penelitian ini membuktikan bekerjanya TPB dalam menentukan pilihan mahasiswa atas program studi akuntansi. Keputusan mahasiswa memilihi program studi akuntansi merupakan intention yang lahir dari perilaku yang terencana dan bukan merupakan keputusan sesaat (Ajzen, 2005). Meskipun revolusi industri 4.0 telah menimbulkan kekhawatiran mengenai program studi termasuk akuntansi, namun hasil penelitain menunjukan bahwa ada banyak aspek yang mempengaruhi intention mahasiswa memilih jurusan akuntansi selain aspek teknologi.

\section{Kesimpulan}

Temuan penelitian membuktikan bahwa intention calon mahasiswa Indonesia memilih jurusan akuntansi masih cukup tinggi. Attitude, norma subjektif, dan kontrol perilaku mempengaruhi intention memilih program studi akuntansi. Intention memilih jurusan akuntansi mahasiswa Indonesia merupakan perilaku yang terencana dan bersifat jangka panjang sehingga dapat dijadikan rujukan untuk menganalisis keberlanjutan penyelengaraan program studi akuntansi di Indonesia. Hasil penelitian ini diharapkan dapat menepis isu-isu negatif mengenai keberlangsungan proram studi akuntansi akibat revolusi industri 4.0 yang kini mulai menjadi persoalan yang serius dihadapi oleh berbagai perguruan tinggi. Meskipun demikian perguruan tinggi harus beradaptasi dengan perubahanperubahan yang ditimbulkan revolusi industri 4.0. 
Hasil penelitian diharapkan menjadi acuan dalam menentukan strategi program studi akuntansi. Sistem informasi mengenai alumni khususnya mengenai karir dan lapangan pekerjaan perlu ditingkatkan kualitasnya karena karir dan lapangan pekerjaan merupakan aspek-aspek yang membangun attitude pemilih jurusan akuntansi. Perguruan Tinggi penting membuat program-program yang mendekatkan untuk membina hubungan baik program studi akuntansi dengan keluarga mahasiswa dan calon mahasiswa karena pemilih jurusan akuntansi khususnya yang berlatar belakang IPA memilih program studi akuntansi atas pertimbangan keluarga.

Penelitian ini hanya menggunakan skala pengukuran likert satu sampai lima yang menyebabkan varian data penelitian terbatas. Disarankan agar penelitian selanjutnya menggunakan skala likert lebih dari 5 (lima) untuk meningkatkan varian data dalam penelitian. Dengan meningkatnya varian data hasil dari penelitian akan lebih mencerminkan pemikiran antara masingmasing responden. 


\section{Daftar Pustaka}

Ajzen, I. (2005). Attitudes, Personality, and Behavior (2nd Edition). Maidenhead: McGraw-Hill Education.

Ajzen, I. (1991). The Theory of Planned Behavior: Organizational Behavior and Human Decision Processes. 50. 179-211.

Alanezi, F. S., Alfraih, M. M., Haddad, A. E. \& Altaher N. A.(2015). Factors Influencing Students' Choice of Accounting as a Major: Further Evidence from Kuwait. Global Review of Accounting and Finance. 7 (1), 165 - 177. Retrived from https://ssrn.com/abstract=2899475

Ali, S. S. S., \& Tinggi, M. (2013). Factors Influencing The Students' Choice of Accounting as a Major. IUP Journal of Accounting Research \& Audit Practices. 12, 4 - 25. Retrieved from https://ssrn.com/abstract=2899475

Alleyne, P., \& Phillips, K. (2011). Exploring Academic Dishonesty Among University Students in Barbados: an Extension to The Theory Of Planned Behaviour. Journal of Academic Ethics, 9(4), 323. https://doi.org/10.1007/s10805-011-9144-1

Andika, M. \& Madjid, I. (2012). Analisis Pengaruh Sikap, Norma Subyektif dan Efikasi Diri Terhadap Intensi Berwirausaha Pada mahasiswa Fakultas Ekonomi Universitas Syiah Kuala. "In Eco-Entrepreneurship Seminar \& Call for Paper" Improving Performance by Improving Environment, 190 - 196. https://doi.org/10.29138/ijebd.v1i2.556

Antaranews.com (2019).Retrieved from https://www.antaranews.com/berita/791557/indonesia-butuh-lebihbanyak-akuntan-publik

Bandura, A. (1977). Self-efficacy: toward a unifying theory of behavioral change. Psychological review, 84(2), 191. Retrieved from http://dx.doi.org/10.1037/0033-295X.84.2.191

Cendrawi, G. P. (2015). Minat Mahasiswa Baru Program Studi Akuntansi Dalam Memilih Jurusan Perkuliahan.Jurnal Ilmiah Mahasiswa FEB, 3(1). Retrieved from https://jimfeb.ub.ac.id/index.php/ jimfeb/article/view/1599/1465

Eagly, A. H., \& Chaiken, S. (1993). The psychology of attitudes. Harcourt Brace Jovanovich College

Publishers.

Hapsari, A.N.S dan Dally Wahyu Seta, D.W (2019). Identifikasi Kecurangan Dan Whistleblowing Universitas, Jurnal Riset Akuntansi Dan Keuangan, 7 (1), 2019, 131-144

Harding, T. S., Mayhew, M. J., Finelli, C. J., \& Carpenter, D. D. (2007). The theory of planned behavior as a model of academic dishonesty in engineering and humanities undergraduates. Ethics \& Behavior, 17(3), 255-279. https://doi.org/10.1080/10508420701519239

Harususilo, Y. E. (2018, November 16). 10 Pekerjaan Ini Akan Segera Digantikan Robot, Apa Saja?. Kompas.com. Retrieved from https://edukasi.kompas.com /read/2018/11/16/09304601/10-pekerjaanini-akan-segera-digantikan-robot-apa-saja?page=all.

Hartono. (2008). Sistem Informasi Keperilakuan. Yogyakarta: Andi.

Islami, N. N. (2017). Pengaruh Sikap Kewirausahaan, Norma Subyektif, dan Efikasi Diri Terhadap Perilaku Berwirausaha Melalui Intensi Berwirausaha Mahasiswa. Jurnal Ekonomi Pendidikan Dan Kewirausahaan, 3(1), 5-20.

Istifarani, F. (2016). Pengaruh Dukungan Keluarga Terhadap Pengambilan Keputusan Karir Siswa Kelas X di SMK Negeri 1 Depok. Jurnal Riset Mahasiswa Bimbingan Dan Konseling, 5(5). Retrived from http://journal.student.uny.ac.id/ojs/ojs/index.php/fipbk/article/view/1403

Joeliatin, J., Murti, B., \& Suryani, N. (2016). Theory of Planned Behavior on the Determinants of Participation in the Long-Term Contraceptive Method Among Women of Reproductive Age, in Nganjuk, East Java. Journal of Health Promotion and Behavior, 1(3), 171-179. Retrived from https://doi.org/10.26911/thejhpb.2016.01.03.04 
Kamal, B. \& Rahmadiane, G. D. (2017). Pengaruh Persepsi, Akreditasi Prodi, Dan Promosi Terhadap Keputusan Memilih Program Studi Akuntansi Pada Politeknik Harapan Bersama. Jurnal Inspirasi Bisnis dan Manajemen, 1 (2),145-158. Retrieved from http://jurnal.unswagati.ac.id/index.php/jibm

Law, P. K. (2010). A theory of reasoned action model of accounting students' career choice in public accounting practices in the post-Enron.Journal of Applied Accounting Research, 11(1), 58-73.Retrived from https://doi.org/10.1108/09675421011050036

Law, P., \& Yuen, D. (2012). A multilevel study of students' motivations of studying accounting: implications for employers. Education+ Training, 54(1), 50-64. Retrrieved from https://doi.org/10.1108/ 00400911211198896

Ningsih, I. S. P., \& Zaky, A. (2014). Determinan Niat Mahasiswa Memilih Konsentrasi Akuntansi dan Keuangan Syariah. Jurnal Ilmiah Mahasiswa FEB, 3(1).

Parker, S. C. (2004). The Economics of Self-Employment And Entrepreneurship. Cambridge England.Cambridge University Press.

Puruhita, R., \& Zaky, A. (2014). Minat Mahasiswa Berlatar Belakang Ilmu Alam Dalam Memilih Jurusan Akuntansi Sebagai Jurusan Perkuliahan. Jurnal Ilmiah Mahasiswa FEB, 3(1).

Porter, J., \& Woolley, D. (2014).An examination of the factors affecting students' decision to major in accounting.International Journal of Accounting and Taxation, 2(4), 1-22. Retrieved from http://dx.doi.org/10.15640/ijat.v2n4a1

Agriyanto, A (2018). Model Rekayasa Perilaku Menggunakan Informasi Akuntansi Berbasis Akrual Pada Organiasi Pemerintah, Jurnal Akuntansi dan Keuangan Indonesia, Juni 2018, Vol. 15, No. 1, hal 77 103

Satya, V. E. (2018, Mei).Strategi Indonesia Menghadapi Revolusi Industri 4.0.Pusat Penelitian Badan Keahlian DPR RI. Retrieved from https://bikinpabrik.id/wp-content/uploads/2019/01/Info-Singkat-X-9-I-P3DIMei-2018-249.pdf

Sugahara, S., \& Boland, G. (2006).Perceptions of the certified public accountants by accounting and nonaccounting tertiary students in Japan.Asian Review of Accounting, 14(1/2), 149-167. Retrived from https://doi.org/10.1108/13217340610729518

Sugahara, S. Suzuki, K., dan Boland, G. (2010). Students' major choice in accounting and its effect on their self efficacy towards generic skills: An Australian study.Asian Review of Accounting. 18 (2) ,131-147. Retrieved from https://doi.org/10.1108/13217341011059390

Suharti, L., \& Sirine, H. (2011). Faktor-faktor yang Berpengaruh terhadap Niat Kewirausahaan (Studi terhadapMahasiswa Universitas Kristen SatyaWacana Salatiga). Jurnal manajemen dan kewirausahaan, 15(2), 124-134.

Sumaryono, S., \& Sukanti, S. (2016). Faktor-Faktor yang Mempengaruhi Niat Mahasiswa Akuntansi Untuk Mengambil Sertifikasi Chartered Accountant. Jurnal Profita: Kajian Ilmu Akuntansi, 4(7).http://journal.student.uny.ac.id/ojs/ojs/index.php/profita/article/view/5906/5644

Tan, L. and Laswad, F. (2006), "Students' beliefs, attitudes and intentions to major in accounting", Accounting Education: An International Journal, Vol. 15 No. 2, pp. 167-87.

Tang, L. C. \& Seng, C. (2016).Factors influence students' choice of accounting major in Cambodian universities.Asian Review of Accounting. 24 (2), 231-251. Retrieved from https://doi.org/10.1108/ARA-04-2014-0049

Wally dan Dima, L. B. (2013). Factors influencing students' choice of accounting as a major: the case of Botswana accounting students. Asian Journal of Empirical Research, 3(4), 464-476.Retrived from : http://aessweb.com/journal-detail.php?id=5004

Wang, X. H., \& LI, W. H.. (2016). How do Chinese high school graduates choose their majors: An analysis based on the individual and family background. Retrieved from https://doi.org/10.2991/hss-26.2016.32 
Wijayanti, A. W., \& Putri, G. A. (2016). Model Theory of Planned Behavior (TPB) Untuk Memprediksi Niat Mahasiswa MelakukanKecurangan Akademik. Fokus Manajerial, 14(2). Retrived from https://jurnal.uns.ac.id/ fokus-manajerial/article/view/8454

Yu, T. H. (2011). Factors that influence high school graduates to choose sport management as their university major in Taiwan (Doctoral dissertation, Texas Woman's University). Retrieved from https://search.proquest.com/docview/883415179?accountid=44931

Lampiran 1. Item Pertanyaan Kuesioner Penelitian

\begin{tabular}{|c|c|c|}
\hline Variabel & Dimensi & Item Pertanyaan \\
\hline Intention & & - Niat Mengambil Jurusan Akuntansi \\
\hline \multirow[t]{3}{*}{ Attitude } & $\begin{array}{l}\text { Aspek Nilai } \\
\text { Intrinsik }\end{array}$ & $\begin{array}{l}\text { - Mengambil jurusan akuntansi akan memberikan pekerjaan yang } \\
\text { menantang } \\
\text { - Saya Tidak menyukai pekerjaan yang menantang } \\
\text { - Mengambil jurusan akuntansi akan memberikan pekerjaan yang } \\
\text { memberi kepuasan } \\
\text { - Mengambil jurusan akuntansi akan meningkatkan prestise di } \\
\text { masyarakat } \\
\text { - Saya tidak menyukai pekerjaan yang dapat meningkatkan prestise }\end{array}$ \\
\hline & $\begin{array}{l}\text { Aspek Pasar } \\
\text { Kerja }\end{array}$ & $\begin{array}{l}\text { Mengambil jurusan akuntansi akan memberikan jaminan hidup } \\
\text { berkualitas di masa mendatang } \\
\text { - Saya tidak menyukai hal yang dapat memberikan jaminan hidup } \\
\text { berkualitas di masa mendatang. }\end{array}$ \\
\hline & $\begin{array}{l}\text { Aspek Prospek } \\
\text { Karir }\end{array}$ & $\begin{array}{l}\text { - Mengambil jurusan akuntansi akan memberikan lapangan } \\
\text { pekerjaan yang luas. } \\
\text { - Saya tidak menyukai hal yang dapat memperluas lapangan } \\
\text { pekerjaan. } \\
\text { - Mengambil jurusan akuntansi akan memberikan pekerjaan } \\
\text { dengan gaji tinggi dalam jangka panjang. } \\
\text { - Saya tidak menyukai pekerjaan yang dengan gaji tinggi dalam } \\
\text { jangka panjang. }\end{array}$ \\
\hline \multirow[t]{3}{*}{$\begin{array}{l}\text { Norma } \\
\text { Subjektif }\end{array}$} & $\begin{array}{l}\text { Aspek } \\
\text { Keluarga }\end{array}$ & $\begin{array}{l}\text { Keluarga / Orang Tua menyarankan untuk mengambil jurusan } \\
\text { akuntansi } \\
\text { - Menerima saran yang di dapat dari Keluarga / Orang Tua }\end{array}$ \\
\hline & $\begin{array}{l}\text { Aspek Teman } \\
\text { Sebaya }\end{array}$ & $\begin{array}{l}\text { - Teman Sebaya menyarankan untuk mengambil jurusan akuntansi } \\
\text { - Menerima saran yang di dapat dari Teman Sebaya }\end{array}$ \\
\hline & Aspek Guru & - Guru menyarankan untuk mengambil jurusan akuntansi \\
\hline
\end{tabular}




\begin{tabular}{|c|c|c|}
\hline & & - Menerima saran yang di dapat dari Guru \\
\hline & $\begin{array}{l}\text { Aspek Role } \\
\text { Model }\end{array}$ & $\begin{array}{l}\text { - Role model menyarankan untuk mengambil jurusan akuntansi } \\
\text { - Menerima saran yang di dapat dari role model }\end{array}$ \\
\hline & $\begin{array}{l}\text { Aspek Pihak } \\
\text { Kampus }(E d u \\
\text { Fair) }\end{array}$ & $\begin{array}{l}\text { - Pihak kampus atau pihak edu fair menyarankan untuk mengambil } \\
\text { jurusan akuntansi } \\
\text { - Menerima saran yang di dapat dari pihak kampus atau edu fair }\end{array}$ \\
\hline & $\begin{array}{l}\text { Aspek Media } \\
\text { Internet }\end{array}$ & $\begin{array}{l}\text { - Media internet memberikan informasi untuk mengambil jurusan } \\
\text { akuntansi } \\
\text { - Menerima informasi dari media internet untuk mengambil } \\
\text { jurusan akuntansi }\end{array}$ \\
\hline \multirow[t]{5}{*}{$\begin{array}{l}\text { Kontrol } \\
\text { Perilaku }\end{array}$} & $\begin{array}{l}\text { Aspek Beban } \\
\text { Kerja }\end{array}$ & $\begin{array}{l}\text { - Mahasiswa jurusan akuntansi memiliki tugas yang banyak. } \\
\text { - Sulit bagi untuk mengambil jurusan akuntansi, jika jurusan } \\
\text { akuntansi memiliki tugas yang banyak. }\end{array}$ \\
\hline & $\begin{array}{l}\text { Aspek } \\
\text { Kemampuan } \\
\text { Matematis }\end{array}$ & $\begin{array}{l}\text { - Mahasiswa jurusan akuntansi harus memiliki kemampuan } \\
\text { matematis yang baik. } \\
\text { - Sulit bagi saya untuk mengambil jurusan akuntansi, karena } \\
\text { jurusan akuntansi membutuhkan kemampuan matematis yang } \\
\text { baik. }\end{array}$ \\
\hline & $\begin{array}{l}\text { Aspek } \\
\text { Pemahaman } \\
\text { Ekonomi }\end{array}$ & $\begin{array}{l}\text { - Mahasiswa jurusan akuntansi harus memiliki pemahaman } \\
\text { ekonomi yang baik. } \\
\text { - Sulit bagi saya untuk mengambil jurusan akuntansi, karena } \\
\text { jurusan akuntansi membutuhkan pemahaman ekonomi yang baik. }\end{array}$ \\
\hline & $\begin{array}{l}\text { Aspek } \\
\text { Pemahaman } \\
\text { Akuntansi }\end{array}$ & $\begin{array}{l}\text { - Mahasiswa jurusan akuntansi harus memiliki pemahaman } \\
\text { Akuntansi yang baik. } \\
\text { - Sulit bagi saya untuk mengambil jurusan akuntansi, karena } \\
\text { jurusan akuntansi membutuhkan pemahaman akuntansi yang } \\
\text { baik. }\end{array}$ \\
\hline & $\begin{array}{l}\text { Aspek } \\
\text { Perkembangan } \\
\text { Teknologi } \\
\end{array}$ & $\begin{array}{l}\text { - Perkembangan teknologi akan menggantikan peran akuntan } \\
\text { - Saya menjadi terdemotivasi untuk mengambil jurusan akuntansi, } \\
\text { karena sebagian fungsi akuntan dapat digantikan oleh teknologi }\end{array}$ \\
\hline
\end{tabular}

